\title{
Range Extension of the Calamaria Reed Snake, Liopeltis calamaria (Günther 1858) from the Western Ghats, Maharashtra, India
}

\author{
Hrishikesh Chunekar ${ }^{1}$ and Shruti Alekar ${ }^{2}$ \\ ${ }^{1} 11$, Sangeeta Society, Vanaz Corner, Kothrud, Pune-411038, Maharashtra, India (hrishi_chunekar@yahoo.com) \\ ${ }^{2} \mathrm{~A} 1 / 21$ Manakarnika, Rambaug Colony, Navi Peth, Pune-411030, Maharashtra, India
}

Photographs by the senior author.

G ünther (1858) described Cyclophis calamaria, Boulenger I(1890) assigned the species to the genus Ablabes, and Wall (1921) referred it to Liopeltis. The Calamaria Reed Snake (Liopeltis calamaria) has been reported in Sri Lanka and India. In India, this species is found in the Western Ghats as far north as Matheran, the Tirunelveli Hills, Mysore Plateau, Bangalore, Chhota Nagpur (Surguja), and the Almora District (Smith 1943). These snakes are light brown, grayishbrown, or greenish in dorsal coloration, often with two moreor-less distinct black longitudinal lines, and a uniformly yellowish venter (Boulenger 1890; Smith 1943).

At approximately $1100 \mathrm{~h}$ on 3 January 2015 , during a trek to the hill Fort Ratangad $\left(19^{\circ} 30^{\prime} \mathrm{N}, 73^{\circ} 41^{\prime} E\right.$; elevation $1,297 \mathrm{~m}$ ), we observed a snake (Fig. 1) basking on a rock near a dry streambed. The snake appeared unusual for this particular region, prompting us to photograph it from several angles with a Canon SX50 HS and collect the snake to confirm identification. The approximate length of the individual was $230 \mathrm{~mm}$. After counting scales, we identified the snake as Liopeltis calamaria. Dorsal scale rows were 15:15:15, ventrals and subcaudals 141 and 68, respectively; preoculars 1; and postoculars 2 . The nasal was not divided, and the third and fourth of seven supralabials extended to the eye. All scalation characters corresponded to those in Smith (1943). After confirming identification, we released the snake at the exact location where it had been collected. A photographic voucher was deposited in the Milwaukee Public Museum, Milwaukee, Wisconsin, USA (MPM P775).

De Silva (1990) noted that Liopeltis calamaria lives close to permanent water sources, but Karunarantha et al. (2004) recorded the species from the drier part of Ritigala in Sri Lanka. Fort Ratangad is situated on the Nagar-Nashik border in Maharasthra, India. Ratangad is generally dry except in June through August during the SW Monsoon. The location where we observed the snake was about $500 \mathrm{~m}$ from a pond, which is the only (albeit inconsistent) source of water at the fort. The individual was a juvenile, suggesting that the species is native to and reproducing in this area of Nashik, approximately $200 \mathrm{~km}$ north of its previously known range.

\section{Acknowledgements}

We thank Akshay Gokhale for spotting the snake, Ashok Captain for confirming the identification of the snake and encouraging us to write this note, Yatish Lele for constant support and encouragement, and Yuvashakti Pune for arranging the trek to Ratangad and constant motivation.

\section{Literature Cited}

Boulenger, G.A.1890. The Fauna of British India, Including Ceylon and Burma. Reptilia and Batrachia. Taylor \& Francis, London.

de Silva, A. 1990. Colour Guide to the Snakes of Sri Lanka. R\&A Publishing Ltd, Avon, England.

Günther, A. 1858. Catalogue of Colubrine Snakes in the Collection of the British Museum. Trustees of the British Museum, London.

Karunarantha, D.M.S.S., D.H.P.U. De Silva, H.T.A.P. Pelris, M.D.C. Asela, U.T.I. Abewardena, A.A.D.A. Udayakumara, D.G.R. Sirimanna, and W.C.C. Soysa. 2004. Two new sightings of Liopeltis calamaria. Journal of the Wildlife and Nature Protection Society of Sri Lanka 23(5-6):23-26.

Smith, M.A. 1943. The Fauna of British India, Ceylon and Burma, Including the Whole of the Indo-Chinese Sub-Region. Reptilia and Amphibia. Volume IIISerpentes. Taylor and Francis, London.

Wall, F. 1921. Ophidia Taprobanica; or, The Snakes of Ceylon. H.R. Cottle, Colombo, Ceylon. 

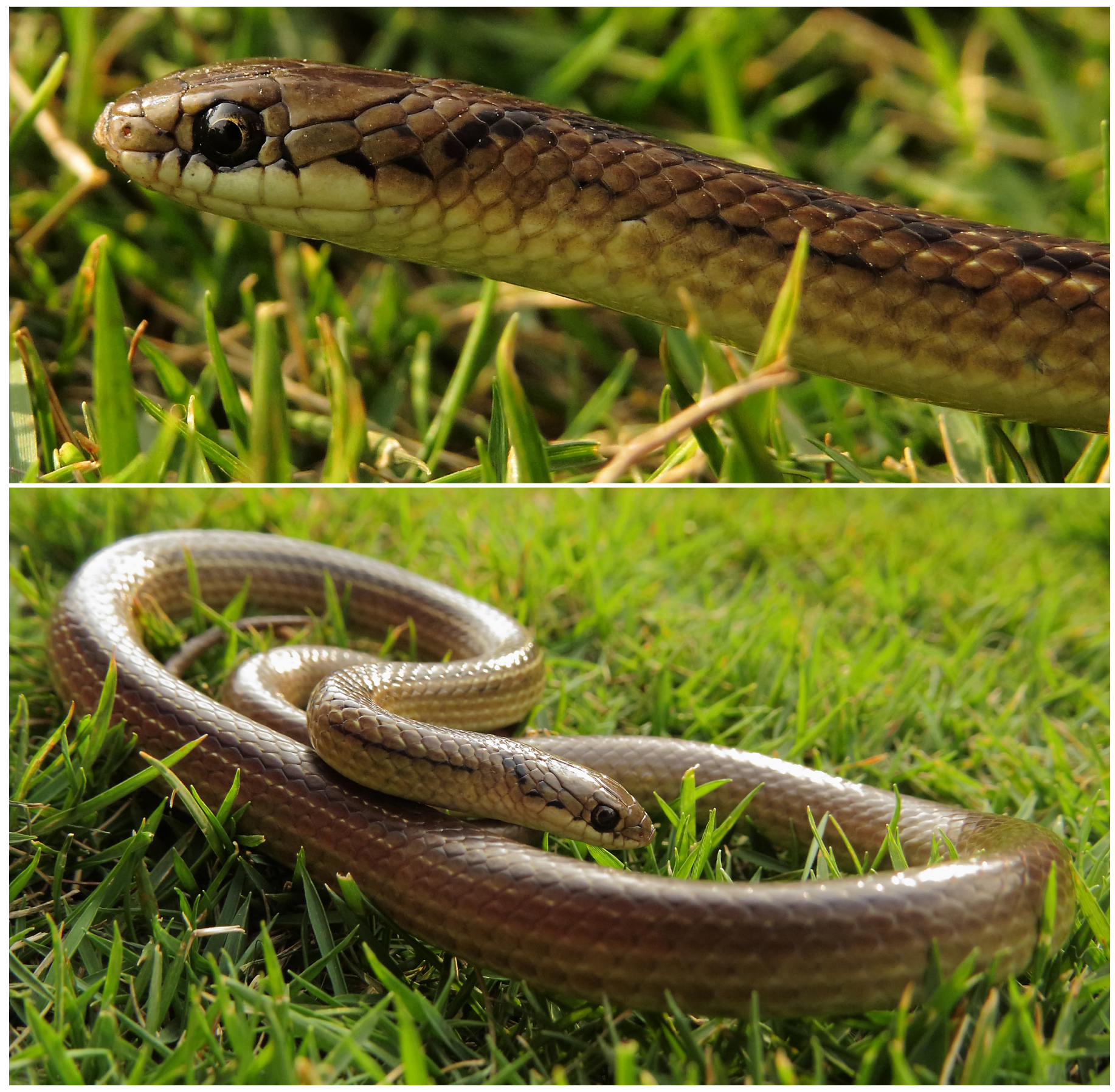

Fig. 1. Calamaria Reed Snake (Liopeltis calamaria) collected at Fort Ratangad on the Nagar-Nashik border in Maharasthra, India $\left(19^{\circ} 30^{\prime} \mathrm{N}, 73^{\circ} 41^{\prime} \mathrm{E}\right.$; elevation $1,297 \mathrm{~m}$ ). 